\title{
Effects of $\mathrm{CO}_{2}$ ratio on emissions of dual fuel diesel engine
}

\author{
Ilker Turgut Yilmaz*, Metin Gumus \\ Department of Mechanical Engineering, Faculy of Technology, Marmara University, DB-103, Göztepe Campus 34722, Istanbul \\ Turkey
}

\begin{abstract}
The problem of energy consumption is growing because of the increase in population. Energy demand is commonly supplied by the fossil fuels however they bring up against the problem of run out. Biogas is a renewable fuel which is a candidate for duel fuel diesel engines. This work focuses on the effect of carbon dioxide on exhaust emission characteristics of a duel fuel diesel engine run on synthetic biogas. Four cylinder, water cooled, turbocharged, a diesel engine with Common Rail fuel injection system is used for this investigation. A simple mixing chamber is placed between inlet manifold and air filter. Experiments have been conducted at $1750 \mathrm{rpm}$ under different loads (50 N.m, 75 N.m and 100 N.m). Main fuels used in this investigation are methane, M60:C40 and M80:C20 in dual fuel mode. In dual fuel mode using biogas increases hydrocarbon, nitrogen oxide and carbon dioxide emissions. Soot emission decrease in duel fuel mode. In the light of experimental data, it is understood that electronic control unit of the diesel engine cannot manage dual fuel mode. Original electronic control unit have to be reprogrammed.
\end{abstract}

Keywords: Biogas, dual fuel diesel engine, emissions

\section{Introduction}

Internal combustion engines (IC) generate power not only vehicles but also other needs. To produce power for vehicles, locomotives, marine, irrigation, production electricity, IC engines need fuel. We commonly use fossil fuels to satisfy these needs. Because of rapidly consumption of fossil fuels, most of the researchers focus their attention on renewable energy sources.

Biogas is a kind of renewable energy which is obtained from organic wastes like agricultural, animal, human wastes [1]. Biogas is produced by anaerobic fermentation of organic wastes. Biogas mainly consists $\mathrm{CH}_{4}$ and $\mathrm{CO}_{2}$. Characteristics of biogas depend on its composition. Its composition changes according to the materials which are used in anaerobic process [2]. $\mathrm{CH}_{4}$ is the energy source and main constituent of biogas.

Table 1. Biogas yield and methane content [3]

\begin{tabular}{lcc}
\hline Feed stock & Biogas yield $\mathrm{m}^{3} / \mathrm{kg}$ & Methane $\%$ \\
\hline Cattle dung & 0.297 & 55 \\
\hline Pig manure & 0.4 & 65 \\
\hline Straw & 0.341 & 51 \\
\hline Spent wash & 0.65 & 65.5 \\
\hline Leaves & 0.21 & 58 \\
\hline Wheat straw & 0.432 & 59
\end{tabular}

Proportions of gases composing biogas vary from feed stock to feed stock. Table 1 shows the some feed stock which are commonly used for producing biogas and biogas yield [3]. Biogas also is called as wet gas, marsh gas, fuel gas, sewer gas, swamp gas [1].

\footnotetext{
* Manuscript received December 23, 2015; revised January 18, 2016.

Corresponding author. Tel.: +902163365770/1468; E-mail address: ilker.yilmaz@ marmara.edu.tr.

doi: $10.12720 /$ sgce.5.1.9-15
} 
Biogas can be used as a main fuel in IC engines in dual fuel mode. Because of low energy density and cetane number, biogas cannot be used as a single fuel in CI engine. The cylinder temperature at the end of compression stroke is almost $553 \mathrm{~K}$. This temperature is not enough to ignite biogas/air mixture. In dual fuel mode, a small amount of diesel fuel is injected in compressed biogas/air mixture to start ignition. Diesel fuel sprayed is called as pilot fuel. Load of IC engine is controlled by main fuel. Biogas is called main fuel. A conventional diesel IC engine needs a gas mixer to run in dual fuel mode. [1], [4]. In this work a simple mixing chamber is placed between inlet manifold and air filter.

Biogas is a popular subject for researchers. Table 2 indicates composition of different biogases.

Table 2. Studies with different composition of biogases

\begin{tabular}{cccccccc}
\hline Study & $\mathbf{C H}_{\mathbf{4}}(\boldsymbol{\%})$ & $\mathbf{C O}(\%)$ & $\mathbf{C O}_{2}(\%)$ & $\mathbf{N}_{\mathbf{2}}(\%)$ & $\mathbf{H}_{\mathbf{2}}(\boldsymbol{\%})$ & $\mathbf{O}_{\mathbf{2}}(\%)$ & $\mathbf{H}_{2} \mathbf{S}(\mathbf{p p m})$ \\
\hline$[5]$ & 73 & --- & 19 & --- & 6,5 & 1,5 & 20 \\
\hline$[6]$ & 64 & --- & 35 & --- & --- & --- & --- \\
\hline$[7]$ & 57 & 0,18 & 41 & --- & 0,18 & --- & --- \\
\hline$[8]$ & $50-70$ & --- & $25-50$ & $0,3-3$ & $1-5$ & --- & --- \\
\hline$[9]$ & $60-80$ & --- & $20-40$ & --- & --- & --- & --- \\
\hline$[10]$ & 68,3 & --- & 31,3 & --- & -- & --- & --- \\
\hline$[11]$ & 60 & 0,18 & 30 & --- & 0,18 & --- & --- \\
\hline
\end{tabular}

Bhaskor, Ujjwal, Soumya and Vijay studied on the effects of compression ratio on the performance, combustion and emission characteristics of raw biogas in a single cylinder dual duel diesel engine. Changes in compression ratio 16 to 18 not only increase thermal efficiencies, $\mathrm{CO}_{2}$ and $\mathrm{NO}_{\mathrm{x}}$ emissions but also decrease $\mathrm{HC}$ and $\mathrm{CO}$ emissions [1]. Choongsoo, Jungsoo and Soonho run a four cylinder spark ignition engine with biogas. They found if amount of $\mathrm{CO}_{2}$ in biogas increased combustion delay and combustion duration increased also burned fuel fraction decreased. Brake power, thermal efficiency and $\mathrm{NO}_{\mathrm{x}}$ emissions all increased with increasing $\mathrm{CH}_{4}$ content and boost pressure [2]. Debabrata and Murugan used biogas produced from pinnata de-oiled cake. They found that optimum biogas flow rate is $0.9 \mathrm{~kg} / \mathrm{h}$ for dual fuel operation. Bsfc, $\mathrm{CO}$ and $\mathrm{HC}$ emissions increased, thermal efficiency, $\mathrm{NO}, \mathrm{CO}_{2}$ and soot emissions dropped with biogas flow rate of $0.9 \mathrm{~kg} / \mathrm{h} \mathrm{[3].} \mathrm{Bhaskor} \mathrm{and} \mathrm{Ujjwal} \mathrm{optimized} \mathrm{compression} \mathrm{ratio}$ and pilot fuel injection time. Maximum thermal efficiency and improvements on $\mathrm{HC}$ and $\mathrm{CO}$ emissions are observed if a combination of pilot fuel injection time of $29^{\circ}$ BTDC and compression ratio of 18 . Also $\mathrm{NO}_{\mathrm{x}}$ and $\mathrm{CO}_{2}$ emissions are found to be the highest with this combination [4].

Increasing of $\mathrm{CO}_{2}$ content of biogas decreases thermal efficiency, combustion temperature and heating value of biogas [7]-[11]. Thermal efficiency can be improved by preheating of inlet air [6], increasing compression ratio [9], using biodiesel as pilot fuel [10], adding $\mathrm{H}_{2}$ in biogas/air mixture [12]. $\mathrm{CO}_{2}$ also effects $\mathrm{NO}_{\mathrm{x}}, \mathrm{CO}$ and $\mathrm{HC}$ emissions [9], [10], [13]. Biogas has almost same properties as compressed natural gas. Because of that it is an alternative fuel for IC engines. Contrary to methane biogas is a renewable energy source and obtained from wastes [14]-[16].

\section{Experimental Setup}

The experimental setup consists of a four cylinder, four stroke, water cooled, turbocharged, $48 \mathrm{~kW}$ diesel engine with Common Rail fuel system. Test engine was connected to a water-cooled eddy current dynamometer. A simple mixing chamber was placed between inlet manifold and air filter. $\mathrm{CH}_{4}$ and $\mathrm{CO}_{2}$ gases were controlled by adjusting valves and measured by flowmeters. Pilot diesel fuel was measured by measuring burette. Energy need of engine was supplied by diesel pilot fuel about $20 \%$. Engine load was controlled by gaseous fuels. Engine was run at 1750 rpm constant speed under 50 N.m, 75 N.m and 100 N.m loads. The specifications of the test engine are listed in Table 3.

Schematic diagram of experimental setup is shown in Fig. 1. Emission analyze was carried out by using Bosch BEA 460 emission analyzer. Emission analyzer has two modules. One of the modules of analyzer is exhaust-gas testing module and the other one is smoke-opacity testing module. Table 4 shows exhaust gas analyzer properties. 
Table 3. Engine specifications

\begin{tabular}{ll}
\hline Cylinder volume & $1461 \mathrm{~cm}^{3}$ \\
\hline Bore & $76 \mathrm{~mm}$ \\
\hline Stroke & $80,5 \mathrm{~mm}$ \\
\hline Number of cylinders & 4 \\
\hline Number of valves & 8 \\
\hline Compression ratio & $18,25: 1$ \\
\hline Maximum power $\mathbf{( 4 0 0 0 ~ d / d ) ~}$ & $48 \mathrm{~kW}(65 \mathrm{hp})$ \\
\hline Maximum torque $\mathbf{( 2 0 0 0} \mathbf{d} / \mathbf{d})$ & $160 \mathrm{~N} . \mathrm{m}$ \\
\hline Fuel injection & Common-Rail \\
\hline Turbocharger & Yes \\
\hline
\end{tabular}

Table 4. Specifications of exhaust gas analyzer

\begin{tabular}{lll}
\hline & Measurement Range & Resolution \\
\hline Carbon dioxide $\left(\mathbf{C O}_{2}\right)$ & $\% 0-18 \mathrm{vol}$. & $\% 0,01 \mathrm{vol}$. \\
\hline Hydrocarbon $(\mathbf{H C})$ & $0-9999 \mathrm{ppm}$ & $1 \mathrm{ppm}$ \\
\hline Oxygen $\left(\mathbf{O}_{2}\right)$ & $\% 0-22 \mathrm{vol}$. & $\% 0,01 \mathrm{vol}$. \\
\hline Nitrogen oxide $\left(\mathbf{N O}_{\mathbf{x}}\right)$ & $0-5000 \mathrm{ppm}$ & $1 \mathrm{ppm}$ \\
\hline Coefficient of absorption $(\mathbf{K})$ & $0-10 \mathrm{~m}^{-1}$ & $0,01 \mathrm{~m}^{-1}$ \\
\hline
\end{tabular}

For the composition of biogas a volume ratio of $\mathrm{CH}_{4}: \mathrm{CO}_{2}$ of $60: 40$ and 80:20 were chosen. Data obtained from biogas/diesel dual fuel engine compared with $\mathrm{CH}_{4} /$ diesel dual fuel engines data.

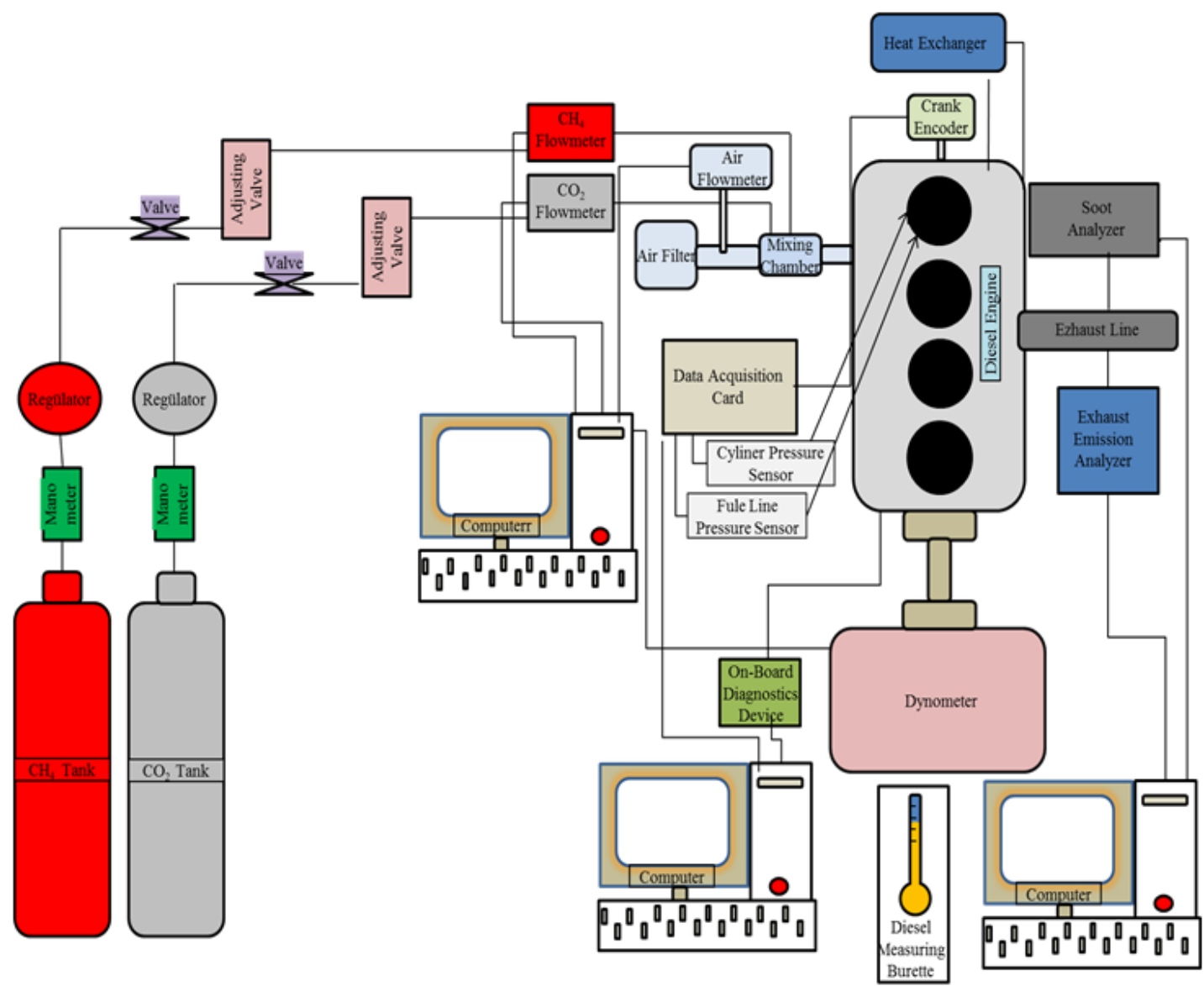

Fig. 1. Schematic diagram of experimental setup. 


\section{Result and Discussion}

The analyses of the investigation is focused on cylinder pressures and exhaust emission analysis.

\subsection{Cylinder pressure}

It can be observed that combustion became in constant volume as seen from the pressure-volume diagram, in Fig. 2.
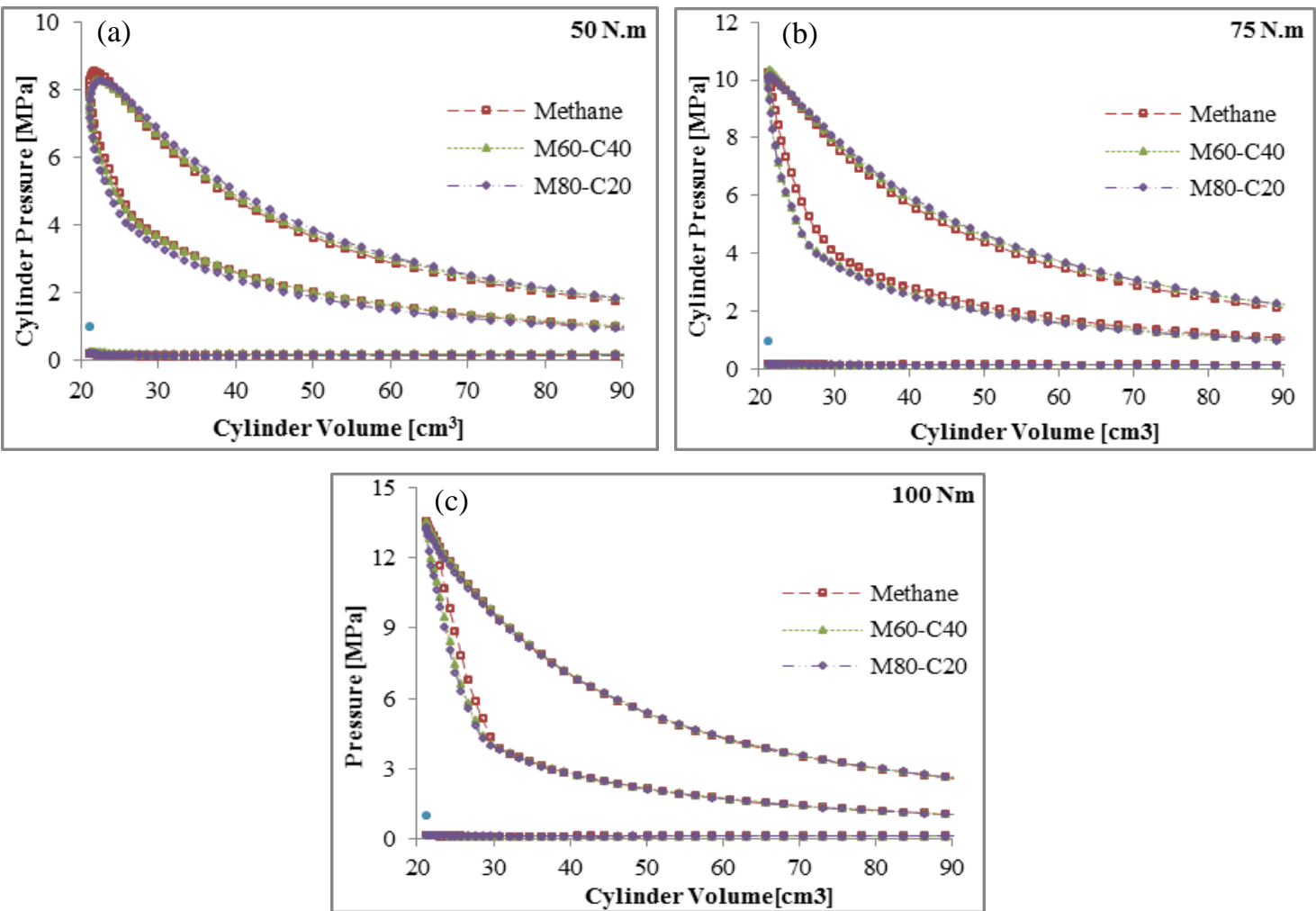

Fig. 2. Variation of pressure with cylinder volume for $\mathrm{CO}_{2}$ ratios: (a) $50 \mathrm{Nm}$, (b) $75 \mathrm{Nm}$ and (c) $100 \mathrm{Nm}$.

Because of the homogenous gas/air mixture, combustion phase passes from constant pressure to constant volume. At 50 N.m load cylinder pressures are 5.54, 8.28 and 8.27 MPa for methane, M60:C40 and M80:C20 dual fuel modes. At 75 N.m cylinder pressures are found 10.25, 10.36 and 10.17 MPa for methane, M60:C40 and M80:C20. At 100 N.m load cylinder pressures rise and they become 13.56, 13.54 and 13.28 MPa. Cylinder pressures rise with increasing load and methane content of gas/air mixture. Constant volume combustion phase causes high pressures but because of the same reason pressure rises cannot be converted to torque.

\subsection{HC emissions}

Lean or rich air/fuel mixtures, misfires and low combustion temperatures are the main factors of HC emissions. The variation in the $\mathrm{HC}$ emissions with load for different $\mathrm{CO}_{2}$ amounts is depicted in Fig. 3. It can be observed from the figure that, $\mathrm{HC}$ emissions decrease with the increase of load and the decrease of $\mathrm{CO}_{2}$ content. This is due to the increase of the ignition energy and number of ignition centers in the combustion chamber. At 50 N.m and 100 N.m loads methane, M60:C40 and M80:C20 dual fuel modes produce nearly same HC emissions about 1.52 and $0.43 \mathrm{~g} / \mathrm{kWh}$. At $75 \mathrm{~N} . \mathrm{m}$ loads HC emissions are 70, 90, $78 \mathrm{~g} / \mathrm{kWh}$ for methane, M60:C40 and M80:C20 dual fuel modes [2], [17]. 


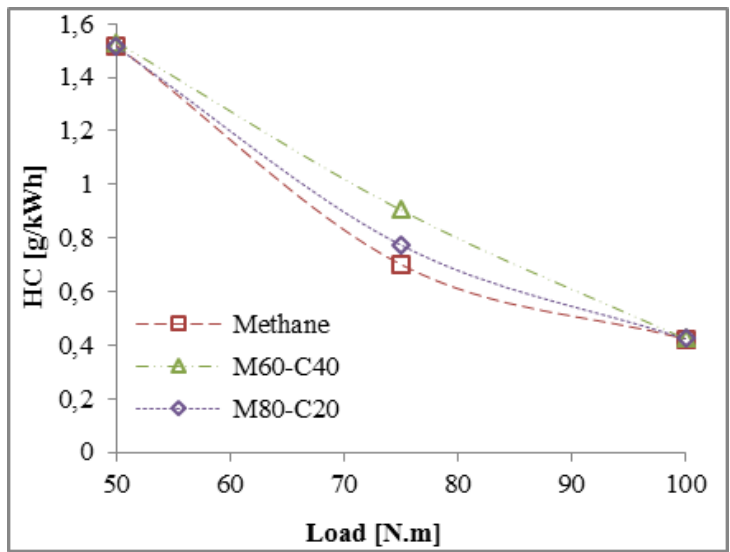

Fig. 3. Variation of $\mathrm{HC}$ with load for different $\mathrm{CO}_{2}$ ratios.

\section{3. $\mathrm{NO}_{x}$ emissions}

$\mathrm{NO}_{\mathrm{x}}$ formation is highly dependent on cylinder temperatures, amount of oxygen and time for the formation reaction. The concentration of $\mathrm{NO}_{\mathrm{x}}$ emissions decrease with the rise of $\mathrm{CO}_{2}$ amount and increase with the rise of load. A lower $\mathrm{NO}_{\mathrm{x}}$ emission of 32.78\% is found in $\mathrm{M} 60: \mathrm{C} 40$ dual fuel operation in comparison to that of methane dual fuel operation at $100 \mathrm{~N} . \mathrm{m}$ load. The presence of $\mathrm{CO}_{2}$ in biogas has a high molar specific heat which dilutes the inlet charge and decrease the combustion chamber temperature. These events suppress $\mathrm{NO}_{\mathrm{x}}$ formation [4], [17]. The variation in the $\mathrm{NO}_{\mathrm{x}}$ emissions with load for different $\mathrm{CO}_{2}$ amounts is depicted in Fig. 4.

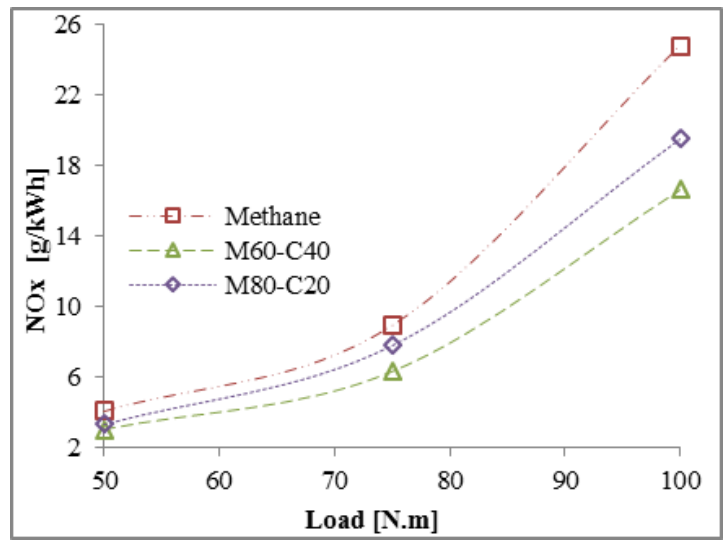

Fig. 4. Variation of $\mathrm{NO}_{\mathrm{x}}$ with load for different $\mathrm{CO}_{2}$ ratios.

\subsection{Soot emissions}

The variation in soot emissions with the $\mathrm{CO}_{2}$ content of biogas at different loads is portrayed by Fig. 5 . It can be observed from the figure soot emissions increase with the increase of load. The soot emissions are higher if the fuel's ratio of hydrogen to carbon lees than 2. Pilot diesel fuel contains aromatic compounds. Increased pilot diesel fuel consumption at relatively high loads increases soot emissions. Not only amount of inlet air but also fuel's oxygen content are the important effects on soot formation [2], [17]. M80:C20 dual fuel operation gives soot emissions lower by about $20 \%$ in comparison with methane dual fuel mode at 100 N.m load. In dual fuel mode some amount of diesel is replaced by the gaseous fuels. The $\mathrm{CO}_{2}$ decreases cylinder temperatures and has a positive impact on soot formation however the fuel's $\mathrm{CO}_{2}$ concentration takes much volume in combustion chamber, combustion detonated and soot emissions increase. 


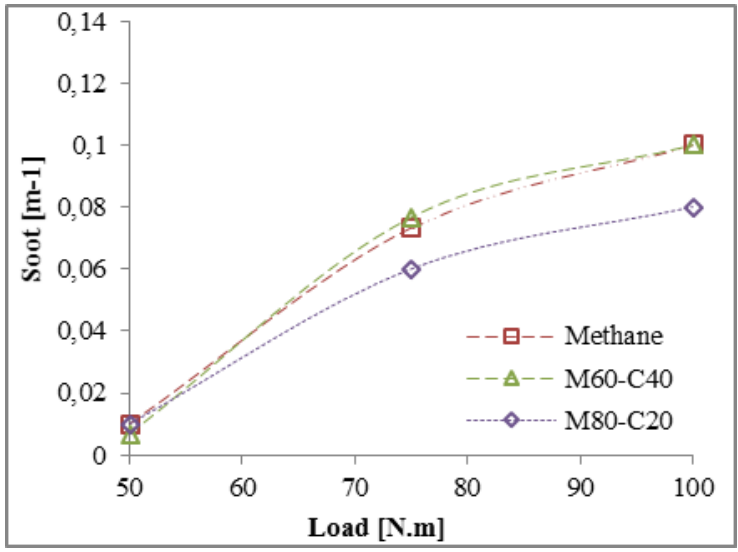

Fig. 5. Variation of soot with load for different $\mathrm{CO}_{2}$ ratios.

\section{Conclusion}

The conclusions of the results obtained from the investigation are as follows:

- Dual fuel operation with methane give maximum cylinder pressures at all loads. However there is no significant pressure differences among other fuels.

- The HC emissions are nearly same at 50 N.m and 100 N.m load. Methane dual fuel mode shows the best $\mathrm{HC}$ emission performance at 75 N.m load.

- The $\mathrm{NO}_{\mathrm{x}}$ emissions in dual fuel operation with M60:C40 are lower by about 26-33\% than methane at all loads.

- Soot emissions are lower in M80:C20 dual fuel mode. Increasing $\mathrm{CO}_{2}$ content of fuel increases soot emissions.

- It is understood that electronic control unit of the diesel engine cannot manage dual fuel mode. Original electronic control unit have to be reprogrammed.

\section{Acknowledgements}

The research has been supported by the Marmara University Scientific Research Commission in Istanbul through the project No. FEN-D.

\section{References}

[1] Bhaskor JB, Ujjwal KS, Soumya C, Vijay V. Effect of compression ratio on performance, combustion and emission characteristics of a dual fuel diesel engine run on raw biogas. Energy Conversion and Management, 2014; 87:1000-1009.

[2] Choongsoo J, Jungsoo P, Soonho S. Performance and $\mathrm{NO}_{\mathrm{x}}$ emissions of a biogas-fueled turbocharged internal combustion engine. Energy, 2015; 86:186-195.

[3] Debabrata B, Murugan S. Investigation on combustion performance and emission characteristics of a DI (direct injection) diesel engine fueled with biogasediesel in dual fuel mode. Energy, 2014; 72:760-771.

[4] Bhaskor JB, Ujjwal KS. Optimisation of injection timing and compression ratio of a raw biogas powered dual fuel diesel engine. Applied Thermal Engineering, 2016; 92:111-121.

[5] Duc PM, Wattanavichien K. Study on biogas premixed charge diesel dual fuelled engine. Energy Conversion and Management, 2007; 48(8):2286-2308.

[6] Yoon SH, Lee CS. Effect of biofuels combustion on the nanoparticle and emission characteristics of a common-rail DI diesel engine. Fuel, 2011; 90(10):3071-3077.

[7] 1Henham A, Makkar MK. Combustion of simulated biogas in a dual-fuel diesel engine. Energy Conversion and Management, 1998; 39(16-18):2001-2009.

[8] Porpatham E, Ramesh A, Nagalingam B. Investigation on the effect of concentration of methane in biogas when used as a fuel for a spark ignition engine. Fuel, 2008; 87(8-9):1651-1659.

[9] Huang JD, Crookes RJ. Assessment of simulated biogas as a fuel for the spark ignition engine. Fuel, 1998; 77(15):1793-1801. 
[10] Crookes RJ. Comparative bio-fuel performance in internal combustion engines. Biomass and Bioenergy, 2006; 30(5):461-468.

[11] Jiang CQ, Liu TW, Zhong JL. A study on compressed biogas and its application to the compression ignition dual-fuel engine. Biomass, 1989; 20(1-2): 53-59.

[12] Porpatham E, Ramesh A, Nagalingam B. Effect of hydrogen addition on the performance of a biogas fuelled spark ignition engine. International Journal of Hydrogen Energy, 2007; 32(12):2057-2065.

[13] Kusaka J, Okamoto T, Daisho Y, Kihara R, Saito T. Combustion and exhaust gas emission characteristics of a diesel engine dual-fueled with natural gas. Jsae Review, 2000; 21(4):489-496.

[14] Ramadhas AS, Jayaraj S, Muraleedharan C. Dual fuel mode operation in diesel engines using renewable fuels: rubber seed oil and coir-pith producer gas. Renewable Energy, 2008; 33(9):2077-2083.

[15] Singh RN, Singh SP, Pathak BS. Investigations on operation of CI engine using producer gas and rice bran oil in mixed fuel mode. Renewable Energy, 2007; 32(9):1565-1580.

[16] Nges IA, Escobar F, Fu XM, Bjornsson L. Benefits of supplementing an industrial waste anaerobic digester with energy crops for increased biogas production. Waste Management, 2012; 32(1):53-59.

[17] Debabrata B, Murugan S. Experimental investigation on the behavior of a DI diesel engine fueled with raw biogasediesel dual fuel at different injection timing. Journal of the Energy Institute (in press). 